\title{
Servitization as a driver for organizational change $\mathrm{e}^{1}$
}

\author{
Ferran Vendrell-Herrero
}

Birmingham Business School, University of Birmingham, Birmingham, United Kingdom

\section{Glenn Parry}

Faculty of Business \& Law, University of the West of England, Bristol, United Kingdom

\section{Oscar F. Bustinza}

Faculty of Economics and Business, University of Granada, Granada, Spain

\section{Nicholas O'Regan}

Faculty of Business \& Law, University of the West of England, Bristol, United Kingdom

\section{Correspondence to:}

Dr Ferran Vendrell-Herrero

Birmingham Business School, University of Birmingham, Edgbaston, Birmingham, B15 2TT, United Kingdom

e-mail: f.vendrell-herrero@bham.ac.uk

\section{One sentence summary:}

Servitization is the move towards selling traditional product to selling a wide range of product-service bundle combinations. This movement contributes to firm sustainability and profitability and hence the competitiveness of nations. This article summarizes the contributions published in this special issue containing academic research on the topic.

\section{Key points:}

1. Servitization directly effects firm performance and territorial competitiveness. The special issue includes articles at both levels of analysis.

2. The effect of servitization is industry specific and hence insights from a wide range of industries are included here; among them engine production, construction, the music industry and cloud computing

\footnotetext{
${ }^{1}$ J.E.L. classification codes: D21 (Firm Behavior);M21 (Business economics)
} 
3. The reduction of cost and the maximization of revenues are the main drivers of servitization. Contributions provide useful methodological insights into implementation of new service business models.

\section{Introduction}

Traditional business models used by manufacturers that exclusively focus on exploiting economies of scale are frequently proving unsuitable for growth, profitability, and firm survival. The addition of service offerings to the portfolio of traditionally product-oriented companies is of growing importance and this special issue publishes work which addresses this observed industry phenomenon dubbed 'servitization' (Vandermerwe and Rada, 1988; Neely, 2008). Servitization is formally described as the process of seeking additional value through taking services propositions to market, and is an academic theme of increasing interest and relevance (Barnett et al., 2013; Bustinza et al., 2013a). This special issue seeks to advance the understanding on the transition undertaken by many firms, not just manufacturers, towards more innovation-based and difficult-to-imitate business models offering bundles of products and services.

The research articles summarized here aimed at both academic and practitioner audiences. The articles were blind reviewed and most were presented at the Second International Conference on Business Servitization, held in Granada, Spain (www.servitization.org) which allowed both formal and informal discussion of specific aspects of the developing research between authors and guest editors. Next section will review the state-of-the-art of servitization literature and further sections will summarize the academic contributions published in this issue.

\section{Theoretical Background}


Vandermerwe and Rada (1988) define servitization as "the increased offering of fuller market packages or 'bundles' of customer focused combinations of goods, services, support, selfservice and knowledge in order to add value to core product offerings" (p. 314). The servitization process has affected a wide range of activities from manufacturing (Neely, 2008), innovation activity (Eggert et al., 2011) and the creative industries sector (Bustinza et al., 2013b; Parry et al., 2012). Different terms have been employed to define the concept in the management literature. Servitization describes how companies consciously transform their businesses into services to gain competitive ground (Vandermerwe and Rada, 1988). Baines et al. (2007) identify five terms used to discuss the phenomenon: Servitization, Product Service Systems, Service Marketing, Service Operations, and Service Science.

According to Wise and Baumgartner (1999), the drivers of servitization are attractiveness of downstream business, importance of customer relationship and power of distribution channel. These drivers use service elements to differentiate manufacturing offerings and provide important competitive opportunities (Gebauer and Fleisch, 2007). Competitive advantage achieved through services is potentially more sustainable since, being less visible and more labour dependent, services are more difficult to imitate (Gebauer et al., 2006) than other strategies focused on product innovation, technological superiority or low prices, making it an important source of competitive advantage. Nevertheless, current empirical research is silent on the organizational change that a firm may experience during the implementation of servitization strategies and its subsequent financial costs and benefits (Pettigrew et al., 2001).

When reading the submissions for the special issue the editors noted the different units of analysis employed, with examples taken from individual firms, groups of firms, regions the support services which facilitate business. This special issue examines the breadth of the impact of servitization across different levels of analysis. The issue begins with industry level 
papers and then challenges the meaning of costs and profit, frequently cited as a driver of servitization. Then follows a paper providing an analysis of how ready a region is for servitization, before the final papers explores IT systems and their role. In the following sections we give more detail of each paper and their relation to theory.

\section{Industry level}

The first paper by Redding presents a strategy development method which leads to greater understanding of an organisations competitive space and facilitates alignment of service offerings, structure, level of technical monitoring support, and the products position in the value chain - the main link to value creation (Holweg and Helo, 2014). A gap analysis approach is employed to provide greater understanding of how the organisation competes against stakeholder expectation. The method allows detailed assessment and understanding of the customer need, internal and external organisational requirements, technologies to support intelligent products and service strategies and aligned service delivery systems. The paper includes the use of health monitoring in complex engineering systems (see more of this literature on Benedettini et al. 2009 and Redding 2011). The process has been validated through application by large multinational firms. The strategy outcomes allow sufficient flexibility such that new service initiatives emerging during operations may be evaluated and adopted.

The paper by Parry and Tasker provides three business-to-business case examples of firms who have moved from provision of manufactured goods to providing service to support their manufactured assets when they are operated by their customers in the field. They categorise these offers as Complex Deployed Responsive Services (Parry et al., 2011). The work provides a framework which acts as a lens for the analysis of the business models used by the firms to provide their service offering (Baden-Fuller and Morgan, 2010; Teece, 2010). 
The elements include the creation of the value proposition; how value is realised in use and mechanisms of worth capture (Sabatier et al., 2010). The proposed framework helps the value creators ensure that they can capture the worth from their offerings such that they are rewarded for their efforts.

Myrthianos et al. examine the evolution of the music industry from 1990 to 2010. The long time period illustrates the impact of servitization on the industry, driven by disruptive innovations (Tidd and Bessant, 2005) which have replaced physical format music with digital music product service systems (Parry et al., 2012). This form of servitization differs from many illustrated in previous literature -see Baines et al. (2009) for a summary- as purchasers rarely bought music in both digital and physical formats. The cannibalistic nature of the new business models causes the industry incumbents to suffer significant declines in total revenue (Parry et al., 2014). The analysis examines and compares the ability of local firms and multinationals in adapting to the servitization phenomenon. Management literature often uses revenues as a proxy for performance, whereas this paper uses firm profits as a more powerful indicator of individual firm success. Consistent with previous literature on the topic (Vendrell-Herrero et al., 2014) analysis confirms there is a link between the fall in industry revenues and firm profits and shows that decrease in profits were greater for local firms than multinationals. The finding contributes to the literature as it suggests that in some cases large firms may be better equipped to adapt to technological and economic disruptions than smaller firms, contradicting existing research on the topic - see for example Hracs (2013).

Galera-Zarco et al. contribute with an analysis of servitization in the construction sector with an examination of Project Based Firms (PBFs), an organizational challenge in business model design and business structure in itself (Davies and Brady, 2006). Project-based firms are typically temporary organizations established to achieve a specific objective rather than continuous activities. The paper examines the case of the construction industry, specifically 
the case of an environmentally efficient architectural firm. PBF business models based on services necessarily change the focus of construction value creation. Construction value creation was previously understood to be within the project-delivery phase, but in this work a more holistic view is taken where the project is understood as a process which includes phases before and after construction and customer's receipt of the building (BlindenbachDriessen and Van den Ende, 2006). Ideally a single firm would be employed to manage a project through life, but whilst progress is being made towards such full servitization the sector in Spain has yet to achieve this goal.

\section{Cost and revenue efficiency}

Thenent et al. provide a paper examining the challenge of costing service systems. One of the key drivers for servitization is the desire to increase revenue and reduce cost (Settanni et al., 2014). Cost prediction methodologies for product manufacture are well understood, but service support cost methods less so. Thenent et al. point out that cost estimators methods traditionally focus upon predicting how much something costs using aggregate data and drawing on past experience. With their focus on producing 'a number' it is rare that a cost estimator will ask why it will cost that much. Further, there is often ambiguity as to which costs are actually meant, how they were determined and for what purpose was the costing undertaken. The work discusses a costing methodology which is suitable for address the problem and context. Thenent et al. suggests building a validated conceptual representation of the socio-technical system underlying the service delivery and that this should be an integral part of cost estimating process. Action and practical implementation of service strategies may be undertaken based on claims made for potential cost savings or increased revenue through service. However, without addressing the concerns raised in the paper such actions may be imprudent. 


\section{Territorial competitiveness}

Current literature is silent with regards analysis of how public policies could encourage the development of service-oriented strategies in companies to foster territorial competitiveness. In fact, while there is burgeoning research on innovation policy and innovation policy mix (Flanagan et al., 2011), there is little explicit analysis of how innovation policy mixes might relate to servitization processes. In this context, Kamp and Alcalde present an analysis of the Basque region of Spain and the readiness of firms there to servitize. The Basque region of Spain provides an interesting case as the area has a strong industrial and manufacturing economic base (Aranguren et al., 2013). The analysis focuses on the value of knowledgeintensive services (KIS) as a proxy for the readiness for servitization of businesses. The analysis highlights a number of issues and areas where investment and support for the region may help firms servitize to reach the stated goals of competing in national and international markets in the knowledge-intensive service area. The analysis contributes to literature by providing a useful case application which other regions may employ to develop service competition and investment policy, highlighting areas for development.

\section{Digital technology}

Sultan examines the Cloud Computing phenomenon, a disruptive innovation that has servitized the IT industry (Vendrell-Herrero and Lafuente, 2014). Cloud computing is the delivery of computing services that were originally only available through physical product support - a construct which has resonance with the paper from the music industry by Myrthianos et al. Cloud computing offers firms a more flexible cost structure, scalability and efficiency for their computing requirements. However, this is a fast developing area and as with many innovations there are issues to address such as the loss of control over resource, 
potential vendor lock-in, and ongoing security, privacy and reliability issues (Sultan, 2013). It is not a panacea and cloud computing may not be suitable for all firms. Cloud computing as a disruptive innovation requires organisations and computing service providers undertake a fundamental and cultural shift in the way they view their IT use and requirement.

Continuing the IT theme Opazo-Basaez et al. examine servitization with regards the increasingly close relationship between customer and provider and how extending IT systems may help facilitate supply chain management. Enterprise Resource Planning (ERP) systems are core IT systems for firms which integrate manufacturing processes and functions with parts and orders in the supply chain (Cannon and Homburg, 2001). It is possible to extend the scope of ERP systems by adding 'bolt-on' extensions which integrate supplier-customer information, creating supply chain management (SCM) systems which provide a holistic view of the extended enterprise from a single IT architecture. The paper contributes to the literature by examining, through a single case context, bolt-on software extensions. Findings indicate that firms engaging in a process of servitization may benefit from CRM and SRM bolt-ons and that these should be integrated into the ERP system to strengthen and facilitate customer and supplier integration.

\section{Conclusions and future research}

The present special issue contributes to a growing literature on service management, product service systems and servitization. The theoretical developments and the qualitative and quantitative evidence provided offer valuable lessons for academics, managers and policy makers. We summarize them below:

- The experimentation and implementation of new business models transforming the production and organizational structure of companies and territories with the inclusion of service activities into the offerings is a growing phenomenon in 
many industries and territories. The special issue offers successful cases in that regard including product support (Parry and Taker) in terms of industry and the Basque country (Kamp and Alcalde) in Spain in terms of region.

- Companies can extract more value from the inclusion of a service offering when using appropriate methodologies. In particular this issue offers relevant and detailed developments on gap analysis (Redding), Cost analysis (Thenent et al.), and Enterprise resource planning (Opazo-Basaez et al.).

- Servitization is not a panacea and in certain circumstances it is not beneficial for many firms in a market. The inclusion of service offering may be forced upon a sector via disruptive innovation. The issue is illustrated with evidence of the music industry (Myrthianos et al.) and Cloud computing (Sultan).

The papers published provide insights into servitization from different perspectives, highlighting areas where there is a need for further research. As a firm's product offering mature they are likely to seek further revenue through provision of services which draw upon their knowledge. We believe that the servitization phenomenon will be an area of significant interest for the upcoming years. In this regard future research may contribute to the development of firms and economies by providing greater understanding of the challenge of servitization and guidance as to how best to proceed in both developing business and research.

\section{References}

Aranguren MJ, Maza-Aramburu X, Parrilli D, Vendrell-Herrero F, Wilson J. 2013. Nested methodological approaches for cluster policy evaluation: An application to the Basque Country. Regional Studies forthcoming.

Baden-Fuller C, Morgan MS. 2010. Business models as models. Long Range Planning 43(2): $156-171$. 
Baines TS, Lightfoot HW, Evans S, Neely A, Greenough R, Peppard J, Roy R, Shehab E, Braganza A, Tiwari A, Alcock JR, Angus, JP, Bastl M, Cousens A, Irving P, Johnson M, Kingston J, Lockett H, Martinez V, Michele P. 2007. State-of-the-art in productservice systems. In Proceedings of the Institution of Mechanical Engineers-Part BEngineering Manufacture 221(10): 1543-1552.

Baines TS, Lightfoot HW, Kay JM. 2009. Servitized manufacture: Practical challenges of delivering integrated products and services. Proceedings of the Institution of Mechanical Engineers Part B-Journal of Engineering Manufacture 223(9): 1207-1215.

Barnett NJ, Parry G, Saad M, Newnes LB, Goh YM. 2013. Servitization: Is a paradigm shift in the business model and service enterprise required?. Strategic Change 22(3-4): 145156.

Benedettini O, Baines TS, Lightfoot HW, Greenough RM. 2009. State-of-the-art in integrated vehicle health management. Proceedings of the Institute of Mechanical Engineers, Part G: Journal of Aerospace Engineering 223(2): 157-170.

Blindenbach-Driessen F, Van den Ende J. 2006. Innovation in project-based firms: The context dependency of success factors. Research Policy 35(4): 545-561.

Bustinza OF, Vendrell-Herrero F, Parry G, Myrthianos V. 2013a. Music business models and piracy. Industrial Management \& Data Systems 113(1): 4-22.

Bustinza, OF, Parry GC, Vendrell-Herrero F. 2013b. Supply and demand chain management: The effect of adding services to product offerings. Supply Chain Management: An International Journal 18(6): 618-629.

Cannon JP, Homburg C. 2001. Buyer-supplier relationships and customer firm costs. Journal of Marketing 65(1): 29-43.

Davies A, Brady T, Hobday M. 2006. Charting a path toward integrated solutions. MIT Sloan Management Review 47(3): 39-48. 
Eggert A, Hogreve J, Ulaga W, Muenkhoff E. 2011. Industrial services, product innovations, and firm profitability: A multiple-group latent growth curve analysis. Industrial Marketing Management 40(2): 661-670.

Flanagan K, Uyarra E, Laranja M. 2011. Reconceptualising the policy mix for innovation. Research Policy 40(5): 702-713.

Gebauer H, Fleisch E. 2007. An investigation of the relationship between behavioural processes, motivation, investments in the service business and service revenue. Industrial Marketing Management 36(3): 337-348.

Gebauer H, Friedli T, Fleisch E. 2006. Success factors for achieving high service revenues in manufacturing companies. Benchmarking: An International Journal 13(3): 374-386.

Hracs BJ. 2013. Cultural intermediaries in the digital age: the case of independent musicians and managers in Toronto. Regional Studies forthcoming.

Holweg M, Helo, P. 214. Defining value chain architectures: Linking strategic value creation to operational supply chain design. International Journal of Production Economics 147(Part B): 230-238.

Neely A. 2008. Exploring the financial consequences of the servitization of manufacturing. Operations Management Research 1(2): 103-118.

Parry G, Bustinza OF, Vendrell-Herrero F. 2012. Servitisation and value co-production in the UK music industry: An empirical study of consumer attitudes. International Journal of Production Economics 135(1): 320-332.

Parry G, McLening M, Caldwell N, Thompson R. 2011. Complex deployed responsive service. In Service Design and Delivery, Macintyre M, Parry G, Angelis J (eds.). Springer: New York; pp. 95-117.

Parry G, Vendrell-Herrero F, Bustinza OF. 2014. Using data in decision-making: Analysis from the music industry. Strategic Change 23(2): 267-279. 
Pettigrew AM, Woodman RW, Cameron KS. 2001. Studying organizational change and development: Challenges for future research. Academy of Management Journal 44(4): $697-713$.

Redding LE. 2011. An introduction to integrated vehicle health management: A perspective from literature. In Integrated Vehicle Health Management: Persectives on an Emerging Field, Jennions IK (eds.). SAE International: Warrendale, PA, USA; pp. 17-26.

Sabatier V, Mangematin V, Rousselle T. 2010. From recipe to dinner: Business model portfolios in the European biopharmaceutical industry. Long Range Planning 43(2-3): $431-447$.

Settanni E, Newnes LB, Thenent NE, Parry G, Goh YM. 2014. A through-life costing methodology for use in product-service-systems. International Journal of Production Economics forthcoming.

Sultan N. 2013. Knowledge management in the age of cloud computing and Web 2.0: Experiencing the power of disruptive innovations. International Journal of Information Management 33(1): 160-165.

Teece DJ. 2010. Business models, business strategy and innovation. Long Range Planning 43(2-3): 172-194.

Tidd J, Bessant J. 2005. Managing Innovation: Integrating Technological, Market and Organizational Change. Wiley: New York.

Vandermerwe S, Rada J. 1988. Servitization of business: adding value by adding services. European Management Journal 6(4): 314-324.

Vendrell-Herrero F, González-Pernía JL, Peña-Legazkue I. 2014. Do incentive matter to promote high technology-driven entrepreneurial activity?. International Entrepreneurship and Management Journal 10(1): 43 -66. 
Vendrell-Herrero F, Lafuente E. 2014. Emprender en la Era Digital: Tres Casos de Emprendedores con Teoría Integrada. Omnia Science: Barcelona.

Wise R, Baumgartner P. 1999. Go downstream: The new profit imperative in manufacturing. Harvard Business Review 77(5): 133-141. 